\title{
IMPLEMENTASI KURIKULUM 2016 BERBASIS KKNI PADA MATA KULIAH SAKUBUN JOKYU DI PROGRAM STUDI PENDIDIKAN BAHASA JEPANG UNIVERSITAS PENDIDIKAN GANESHA
}

\author{
P.Deviliastari, W. Sadyana, G.S. Hermawan. \\ Program Studi Pendidikan Bahasa Jepang, Univeritas Pedidikan Ganesha \\ Singaraja, Indonesia \\ e-mail: putudeviliastari@undiksha.ac.id \\ wayan.sadyana@undiksha.ac.id satya.hermawan@undiksha.ac.id
}

\begin{abstract}
Abstrak
Penelitian ini bertujuan untuk menganalisis implementasi kurikulum berbasis KKNI pada mata kuliah sakubun jokyu di Program Studi Pendidikan Bahasa Jepang Universitas Pendidikan Ganesha yang meliputi persiapan, penerapan, penilaian dan evaluasi serta proses pencapaian capaian pembelajaran. Subjek penelitian ini adalah dua dosen mata kuliah sakubun jokyu di Program Studi Pendidikan Bahasa Jepang. Analisis data dengan menggunakan teknik deskriptif kualitatif. Metode pengumpulan data dengan metode observasi, wawancara dan dokumentasi. Hasil penelitian yaitu (1) perencanaan pembelajaran sakubun jokyu telah memenuhi standar perencanaan yang diatur oleh Universitas Pendidikan Ganesha, (2) pelaksanaan pembelajaran dengan strategi ekspositori, ceramah, latihan dan penugasan, (3) penilaian dengan menekankan pada UAS, (4) evaluasi dilakukan dengan review diawal maupun diakhir pembelajaran, selain itu dengan UTS dan UAS. Pada capaian pembelajaran sakubun jokyu telah terpenuhi sesuai dengan tuntutan pembelajaran
\end{abstract}

Kata Kunci : KKNI, Implementasi, Mata Kuliah Sakubun Jokyu.

\section{要旨}

本研究の目的は、ガネーシャ教育大学日本語教育学科の作文上級クラスにおいて、学習の計画、 実施、評価の含むインドネシア国家資格枠組に基づく２０１６カリキュラム実施がど、評価、 そして、学習成果を達成するプロセスのように行われるかを分析する。調査協力者は、ガネシ 中教育大学日本語教育学科の作文上級クラスの 2 名担当教師である。調査方法は、観察、イン タビュー及び文献調查である。このデータを定性的記述法により分析した。分析した結果、1) 作文上級の授業計画はガネーシャ教育大学によるインドネシア国家資格枠組に基づく計画基準 を満たしている。2）授業実施は説明戦略、講義、練習、課題を使用した。3）インドネシア 国家資格枠組の計画は、期末試験での活気の評価に中心になる。4）評価は最初と最後の授業 の復習、及び中間試験期末試験で害行された。作文上級の授業は学習の要求に従って満たされ てる。 キーワード : インドネシア国家資格枠組、実施、作文上級クラ 


\section{PENDAHULUAN}

Kurikulum merupakan salah satu sistem yang mengatur jalannya pendidikan dan sebagai panduan dalam jalannya sebuah pembelajaran. Pembentukan sebuah kurikulum harus mampu menjawab tuntutan dari masyarakat. Melalui kurikulum akan menentukan kualitas dan arah dalam suatu pembelajaran. Selain itu kurikulum juga harus menyesuaikan dengan era tertentu. Dalam kurikulum ada visi misi tertentu, begitu pula dengan adanya beberapa perubahan yang dilakukan oleh suatu lembaga pendidikan atau pengguna kurikulum. Dalam satu kurikulum akan mempunyai visi misi yang berbeda dengan kurikulum yang lainnya. Maka dari itu dengan dilakukan perubahan kurikulum diharapkan agar proses atau tuntutan pembelajaran semakin baik kedepannya.

Dalam pembuatan kurikulum menggunakan pedoman yang sesuai dan diatur dalam Keputusan Menteri Pendidikan Nasional Republik Indonesia no. 232/u/2000 tentang penyusunan kurikulum dan hasil belajar mahasiswa. Dalam pasal 1 ayat 5 Keputusan Menteri Pendidikan Nasional Republik Indonesia no. 232/u/2000 tentang program studi sebagai pedoman dan alat penyelenggaraan akademik yang bertujuan agar mahasiswa dapat memiliki pengetahuan, keterampilan dan sikap yang sesuai dengan kurikulum. Seperti kurikulum KKNI yang merupakan kerangka acuan yang dijadikan acuan dalam jenjang pendidikan dan sebagai penyanding, penyetaraan dan pengintegrasian antara bidang pendidikan dan pelatihan kerja dalam pemberian pengakuan dalam kompetensi kerja sesuai dengan struktur.

Pada kurikulum KKNI yang tertera pada Perspres No. 49 tahun 2014 pemendikbud No. 73 tahun 2013 tentang capaian pembelajaran sesuai dengan level KKNI. UU PT No. 12 tahun 2012 pasal 29 tentang kompetensi lulusan yang mengacu pada KKNI. Maka capaian pembelajaran setiap mata kuliah harus mengacu pada KKNI.

Pada program studi Pendidikan Bahasa Jepang yang sudah melakukan perubahan kurikulum sebanyak tiga kali, yaitu pertama menggunakan kurikulum 2011, kedua menggunakan kurikulum 2014 dan yang terakhir menggunakan kurikulum KKNI (Kerangka Kualifikasi Nasional Indonesia). Tentu dalam perubahan kurikulum diharapkan untuk pembelajaran lebih baik.

Perubahan kurikulum akan mempengaruhi beberapa faktor, seperti proses pengajaran di kelas, capaian pembelajaran, kemampuan mahasiswa hingga penilaian. Dalam kurikulum KKNI dapat dikatakan pembelajaran berpusat pada mahasiswa (student center), sehingga pembelajar dituntut untuk lebih mendekatkan diri pada proses pembelajaran. Pembelajaran yang dimaksud adalah mahasiswa yang diberikan suatu materi kemudian harus menemukan masalah dalam materi tersebut, memecahkan masalah dalam materi tersebut hingga mendapat jawaban pada masalah tersebut. Dengan begitu tugas dari pengajar adalah sebagai pengawas serta mengkonfirmasi jawaban dari mahasiswa. Maka dari itu penelitian ini menarik untuk diteliti karena dapat melihat apakah tuntutan kurikulum KKNI sudah diterapkan dengan baik dalam pembelajaran. Penelitian ini menarik diteliti karena untuk melihat capaian pembelajaran pada mata kuliah Sakubun Jokyu dengan menggunakan kurikulum KKNI.

Penelitian jenis KKNI pernah dilakukan oleh A.Fatoni yang meneliti tentang Manajemen Pengembangan Kurikulum Berbasis KKNI. Penelitian ini tentang perkembangan kurikulum dalam pembelajaran dan fungsinya. Keterkaitan penelitian yang sebelumnya dengan yang sekarang adalah penelitian sebelumnya berfokus pada konsep manajemen kurikulum KKNI dan penelitian sekarang berfokus aplikasi kurikulum KKNI pada proses pembelajaran.

\section{KAJIAN PUSTAKA}

\section{Pengertian Kurikulum KKNI}

Kurikulum adalah pengalaman belajar yang terarah dan terstruktur yang tersusun dalam proses rekuntruksi dan pengalaman belajar secara sistematis yang berada dalam 
pengawasan lembaga pengajar, sehingga pembelajar memiliki motivasi dan minat belajar, menurut Tanner.

Kurikulum KKNI (Kerangka Kualifikasi Nasional Indonesia) adalah kerangka penjenjangan kualifikasi yang dapat menyetarakan, menyandingkan dan mengintegrasikan bidang pendidikan dan bidang pelatihan kerja maupun pengalaman kerja dalam pemberian pengakuan kompetensi kerja dari berbagai sektor. Kurikulum berbasis KKNI memiliki makna perubahan dalam pelaksanaan pembelajaran, penciptaan suasana akademik, dan cara evaluasi dalam menunjang tujuan pendidikan, dan kurikulum memiliki peran sebagai kebijakan menajemen pendidikan tinggi yang dapat digunakan untuk menentukan arah pendidikan. Pada penerapan kurikulum berbasis KKNI ini diharapkan kualitas pendidikan di Indonesia semakin maju, karena KKNI ini merupakan kerangka acuan yang dijadikan ukuran dalam pengakuan penjenjangan suatu lembaga kependidikan. KKNI disusun dalam rangka menciptakan standar lulusan yang dapat diakui secara nasional dengan harapan mampu bersaing di luar negeri.

\section{Landasan Kurikulum KKNI}

Penyusunan KKNI mempunyai landasan hukum, yang tercakup di dalam UndangUndang Nomor 13 Tahun 2003 tentang Ketenagakerjaan, Peraturan Pemerintah Nomor 31 Tahun 2006 tentang Sistem Pelatihan Kerja Nasional dan Peraturan Pemerintah Nomor 23 Tahun2004 tentang Badan Nasional Sertifikasi Profesi. Selain itu KKNI ini juga disusun untuk memenuhi amanat Undang-Undang Nomor 20 Tahun 2003 tentang Sistem PendidikanNasional. Dalam Pasal 4 ayat (2) undang-undang tersebut menyatakan bahwa pendidikan diselenggarakan sebagai satu kesatuan yang sistemik dengan sistem terbuka dan multimakna.

\section{Pengembangan Kurikulum KKNI}

Dalam pengembangan kurikulum KKNI secara umum diharapkan melahirkan suatu penyetaraan sistem pencapaian kualifikasi ketenaga kerjaan dan dimana Indonesia menganut unified system atau sistem terpadu dalam capaian pembelajaran untuk jenis pendidikan akademik, vokasi maupun profesi dianggap sama untuk jenjang kualifikasi yang sama. Penerapan KKNI sejauh ini mencakup area pendidikan tinggi dan ketenagakerjaan. Pengembangan penyetaraan KKNI di Indonesia memiliki beberapa sifat, salah satunya yaitu $\mathrm{KKNI}$ harus mencakup pengembangan sistem penjaminan mutu yang memiliki fungsi pemantauan (monitoring) dan pengkajian (assessment) terhadap badan atau lembaga yang terkait dengan proses-proses penyetaraan capaian pembelajaran dengan jenjang kualifikasi yang sesuai dalam bidang pendidikan. Kemudian dalam bidang ketenaga kerjaan yaitu KKNI harus dapat menjadi panduan bagi para pencari kerja yang baru maupun para pekerja lama dalam upaya meningkatkan taraf hidup atau karir ditempat kerja masing-masing.

\section{Pendekatan Kurikulum KKNI}

Di dalam pengembangannya, jenjang-jenjang kualifikasi pada KKNI merupakan jembatan untuk menyetarakan capaian pembelajaran yang diperoleh melalui pendidikan formal, informal, dan nonformal dengan kompetensi kerja yang dicapai di dunia kerja, melalui pelatihan berbasis kompetensi (Competence Based Training $=\mathrm{CBT}$ ) atau program peningkatan jenjang karir.

Misalnya, Di dalam pengembangannya, jenjang-jenjang kualifikasi pada KKNI merupakan jembatan untuk menyetarakan capaian pembelajaran yang diperoleh melalui pendidikan formal, informal, dan nonformal dengan kompetensi kerja yang dicapai di dunia 
kerja, melalui pelatihan berbasis kompetensi (Competence Based Training $=$ CBT) atau program peningkatan jenjang karir.

Konsep dasar KKNI tersebut mengandung makna kesetaraan dan pengakuan yang disepakati bersama antar pemangku kepentingan. Oleh karena itu KKNI harus dilengkapi dengan mekanisme dan aturan-aturan yang diperlukan untuk mewujudkan kesetaraan dan adanya saling pengakuan. Dalam ranah pendidikan, dunia kerja dan keprofesian, mekanisme dan aturan-aturan tersebut mungkin telah ada dan disusun dengan baik, akan tetapi untuk ranah masyarakat luas hal ini memerlukan panataan yang komprehensif dengan memperhatikan unsur-unsur mutu, akuntabilitas dan integritas.

\section{Pembelajaran sakubun di Undiksha}

Kata sakubun berasal dari kanji tsukuru dan fumi/bun. Terlihat dari maknanya sakubun memiliki makna menulis. Dalam konteksnya sakubun diartikan juga sebagai karangan (dewi,2015). Sakubun (mengarang) adalah kegiatan mengekspresikan kalimat yang pada dasarnya pemikiran muncul dari pemahaman membaca, menyimak dan mendengarkan serta dalam kegiatan lainnya yang diterapkan dalam kegiatan menulis (Ogawa, 1993). Sakubun adalah kalimat yang dasar pemikirannya berasal dari kegiatan menyimak dan menulis dan kegiatan ekspresi lain sesuai dengan kosakata dan tata bahasa yang benar, Uchiyama (dalam Dewi, 2015).

Dalam mata kuliah sakubun jokyu adapun capaian pembelajaran yaitu,

1. Sikap :

a. harus memiliki tanggung jawab dalam menyelesaikan tugas

b. mampu menulis artikel ilmiah dalam Bahasa Jepang dengan baik serta dapat mempresentasikannya.

2. Pengetahuan :

a. mengenal konsep teoritik tentang kosakata

b. mengenal konsep teoritik tentang pola kalimat

c. mengenal konsep teoritik tentang tuturan Bahasa Jepang khususnya Bahasa Jepang tulis yang diterapkan dalam membuat artikel ilmiah dan penguasaan dalam mempresentasikannya.

3. Keterampilan umum :

a. telah mengenal dan mengetahui kosakata

b. telah mengenal dan mengetahui pola kalimat

c. telah mengenal dan mengetahui tuturan Bahasa Jepang ragam tulis dalam bentuk membuat artikel ilmah dengan menunjukkan penguasaan yang baik alam memahami kosakata, pola kaliamat ragam tulis dan kesesuaian tema yang ditentukan.

d. Kemudian mampu dalam menuliskannya dalam bentuk huruf jepang ( hiragana, katakana dan kanji) serta mampu mempresentasikannya.

4. Keterampilan khusus

a. terampil dalam memahami kosakata

b. terampil dalam memahami pola kalimat

c. terampil dalam memahami Bahasa Jepang ragam tulis yang diterapkan dalam bentuk membuat artikel ilmiah

d. mampu menuliskan artikel ilmiah dalam huruf Jepang (hiragana, katakana dan kanji) serta mampu mempresentasikannya. Tema dapat disesuaikan dengan pilihan penelitian mahasiswa.

\section{Metode}




\section{a. Metode wawancara}

Wawancara adalah suatu proses yang mengharuskan penafsiran dan penyesuaian terus menerus. Wawancara adalah salah satu cara untuk mencari fakta dengan mengingat dan merekontruksi sebuah peristiwa dan mengintip pendapat maupun opini nara sumber, menurut Suhandang (2004). Metode wawancara yang dilakukan yakni dengan mewawancarai mahasiswa dan pengampu mata kuliah sakubun. Metode wawancara dilakukan untuk mengetahui tingkat kesulitan yang dialami dan pengajaran yang dilakukan. Wawancara kepada pengampu mata kuliah sakubun dilakukan untuk mengetahui proses dalam pembelajaran, wawancara kepada mahasiswa angkatan 2017 dilakukan untuk mengetahui tingkat kesulitan yang dialami dalam pembelajaran sakubun.

b. Metode Observasi

Observasi adalah suatu cara untuk memperoleh data dengan mengadakan pengamatan yang sistematis. Pengamatan yang dimaksud bisa secara lengkap pada dokumen atau pencatatan sensus, menurut Sugiyono (2010:140). Metode observasi dilakukan untuk mengetahui keadaan kelas serta melakukan pengamatan secara langsung dalam proses pembelajaran. Observasi yang dilakukan yaitu dengan cara mengamati keadaan kelas maupun mengamati mahasiswa dalam proses pembelajan. Dalam observasi selain untuk mengamati proses pembelajaran yaitu untuk mendapatkan data apakah sudah maksimal pembelajaran itu berlangsung atau tidak. Serta untuk melihat apakah sudah tepat atau tidaknya panduan pembelajaran digunakan dengan situasi di kelas.

c. Metode Dokumentasi

Dokumentasi merupakan istilah internasional. Dalam bahasa Inggris disebut documentation. Dalam bahasa Latin disebut documentum yang berarti pencarian, penyelidikan, pengumpulan, penyusunan, pemakaian, dan penyediaan dokumen untuk mendapatkan keterangan-keterangan dan penerapan-penerapan dan bukti. Salah satu pengertian dokumentasi menurut ahlinya yaitu, menurut FID (Federation Internationale de Documentation) dokumentasi adalah pekerjaan mengumpulkan, menyusun dan menyebarluaskan dokumen dari segala macam jenis lapangan aktivitas manusia. Bisa dikatakan dokumentasi adalah suatu pekerjaan yang bertugas mencari, mengumpulkan, menyusun, menyelidiki, meneliti, dan mengolah serta memelihara data dan menyiapkan sehingga menjadi dokumen baru yang bermanfaat. Metode dokumentasi dilakukan dengancara mendokumentasikan proses pembelajaran di dalam kelas dalam bentuk foto maupun video. Dengan foto dan video maka dapat dianalisis proses pembelajaran.

Dalam metode dokumentasi adalah untuk mengumpulkan dokumen-dokumen yang berkaitan dengan pembelajaran, baik itu dokumen berupa RPS, silabus, foto maupun video. Tujuan dari pengumpulan dokumen tersebut untuk dibahas dan diteliti pada tahap selanjutnya.

\section{Hasil Dan Pembahasan}

\section{A. HASIL PENELITIAN}

Tabel 4.1 Cek List Pemenuhan Komponen Perencanaan Pembelajaran

\begin{tabular}{|c|c|c|c|c|}
\hline \multirow[t]{2}{*}{ No } & \multirow[t]{2}{*}{ Pernyataan Kriteria } & \multicolumn{2}{|c|}{ Pemenuhan } & \multirow[t]{2}{*}{ Dokumen } \\
\hline & & Ya & Tidak & \\
\hline 1. & Identitas mata kuliah & & & $\begin{array}{l}\text { Silabus, RPS dan } \\
\text { Kontrak kuliah }\end{array}$ \\
\hline 2. & \begin{tabular}{lrr} 
Capaian & \multicolumn{2}{c}{ pembelajaran, } \\
kemampuan & akhir yang \\
diharapkan & &
\end{tabular} & & & $\begin{array}{l}\text { Silabus, RPS dan } \\
\text { Kontrak kuliah }\end{array}$ \\
\hline 3. & $\begin{array}{l}\text { Kriteria, indikator dan bobot } \\
\text { penilaian }\end{array}$ & & & $\begin{array}{l}\text { Silabus, RPS dan } \\
\text { Kontrak kuliah }\end{array}$ \\
\hline
\end{tabular}




\begin{tabular}{|r|l|l|l|}
\hline 4. & Pengalaman belajar mahasiswa & & RPS \\
\hline 5. & Metode pembelajaran & & RPS \\
\hline 6. & $\begin{array}{l}\text { Waktu pelaksanaan } \\
\text { pembelajaran }\end{array}$ & & $\begin{array}{l}\text { Silabus, RPS dan } \\
\text { Kontrak kuliah }\end{array}$ \\
\hline 7. & Daftar reverensi yang digunakan & & RPS \\
\hline
\end{tabular}

Jadi berdasarkan data diatas, maka dokumen pada perencanaan pembelajaran pada mata kuliah Sakubun Jokyu terpenuhi. Perencanaan pembelajaran seperti silabus dan RPS (rancangan perkuliahan semester) sudah dipersiapkan oleh dosen. Mengingat RPS dan silabus adalah bagian dari perencanaan pembelajaran yang di dalamnya terdapat materi, metode pembelajaran, waktu pembelajaran maupun jadwal perkuliahan.

\section{Hasil Wawancara}

Berdasarkan wawancara yang dilakukan pada tanggal 31 mei 2019 dengan pengampu mata kuliah Sakubun Jokyu bahwa aplikasi pembelajaran dilakukan sesuai dengan RPS. Dengan berpedoman pada RPS maka pembelajaran terlaksana dengan tepat sesuai dengan waktu yang sudah ditentukan yaitu 16 kali pertemuan. Dengan adanya 2 pengampu mata kuliah Sakubun Jokyu maka dalam 16 kali pertemuan dibagi menjadi 2 bagian, bagian pertama pada pertemuan pertama sampai pertemuan ke tujuh sampai UTS diampu oleh dosen pengampu pertama. Setelah UTS hingga pertemuan terakhir UAS diampu oleh dosen kedua.

Pada proses pembelajaran menggunakan satu RPS sehingga materi yang diajarkan sudah terperinci. Alasan mata kuliah Sakubun Jokyu diampu oleh 2 dosen karena banyaknya mata kuliah yang diampu oleh dosen, sehingga dilakukan Team Teaching pada mata kuliah Sakubun Jokyu. Maka dari itu untuk mengantisipasi, seperti ditiadakannya perkuliahan atau materi yang tertinggal maka dosen memutuskan untuk mata kuliah diampu oleh 2 dosen. Tugas dari kedua dosen tetap sama yaitu memberikan materi, tugas hingga revisi pada setiap pertemuan dan setiap dosen juga melihat perkembangan masing-masing proses pembelajaran pada mahasiswa.

Cara penilaian dari masing-masing dosen tetap sama yaitu dilihat dari proses, bagaimana setiap mahasiswa mampu untuk menerima materi dengan baik, dan dari keaktifan mahasiswa dalam kelas, seperti bertanya, memberikan pendapat pada saat pembelajaran dan absensi pada setiap pertemuan. Selain itu ada pula penilaian tugas, dimana setiap mahasiswa bertanggung jawab pada setiap tugas yang diberikan, sesuai dengan capaian pembelajaran yang tertera pada RPS. Kemudian hasil yang terakhir dilihat yaitu nilai, berupa hasil akhir dari ujian (UTS dan UAS).

Dari hasil wawancara yang dilakukan dapat dikatakan bahwa pada pembelajaran Sakubun Jokyu tetap berpedoman dari RPS maupun capaian pembelajaran yang sudah ditetapkan. Pada pembelajaran dosen menggunakan batas pengajaran yang diukur melalui capaian pembelajaran. Seperti pengajaran yang dilakukan pada setiap pertemuan, dosen tidak hanya menilai dan melihat bagaimana proses pembelajaran itu terjadi. Tetapi dosen akan melihat apakah capaian pembelajaran itu sudah tercapai apa belum. Karena capaian pembelajaran merupakan pedoman dalam mengukur suatu pembelajaran.

\section{Hasil Observasi Pertama}

Observasi pertaman dilakukan pada hari Jumat, 26 November 2018 pada pukul 10.0011.30. Observasi dilakukan pada pertemuan ke 3 dengan materi 注意書きのメモ /chuikakinomemo (pengumuman peringatan). Pada pertemuan ke 3 dosen menyiapkan sumber belajar seperti media power point dan materi berupa hard copy yang sudah dibagikan. Dosen melakukan absensi dengan bertanya kepada korti. 
Pada pertemuan ini dosen langsung memberikan materi yang sudah disiapkan dan membahas bersama-sama. Pada setiap materi dosen memberikan kesempatan pada mahasiswa untuk bertanya jika belum bisa dipahami. Maka tidak sedikit mahasiswa yang antusias dan bertanya sehingga terkesan keaktifan cukup baik. Dengan banyaknya pertanyaan dari mahasiswa sering terjadi kekurangan waktu sehingga setelah diakhirnya perkuliahan masih banyak mahasiswa yang bertanya.

Sebelum dimulainya materi dosen terlebih dahulu memberiksn contoh yang ada pada kehidupan nyata seperti, "hati-hati ada perbaikan jalan", "hati-hati ada upacara agama". Setelah itu mahasiswa diberikan kosakata yang tepat untuk materi chuikakinomemo (pengumuman peringatan). Mahasiswa juga diberi kesempatan untuk bertanya ide apa yang nanti digunakan sebagai tugas. Dengan begitu jika ada yang kurang tepat maka dibahas bersama sehingga kesalahan tidak digunakan lagi untuk mahasiswa yang lain. Setelah melakukan diskusi dan pembahasan materi maka seperti biasa ada tugas yang akan dikumpul pada pertemuan selanjutnya.

Pada setiap pertemuan akan ada tugas yang diberikan dan diperiksa. Seperti halnya pertemuan ini, setalah pembahasan materi selesai maka dilanjutkan dengan pembahasan tugas yang sudah dikumpul. Pembahasan melalui media power point, pada media itu sudah terdapat tugas yang berupa gambar dari masing-masing mahasiswa. Tugas dibahas satu persatu sehingga setiap mahasiswa akan mengetahui kesalahannya. Setelah selesai membahas tugas maka dilanjutkan dengan memberikan tugas untuk dikumpul pertemuan selanjutnya. Tugas yang diberikan yaitu berkaitan dengan materi terkait yaitu chuikakinomemo (pengumuman peringatan).

Diakhir pembelajaran dosen memberikan fukushu dan kesempatan untuk bertanya jika ada yang belum dipahami. Dengan begitu banyak mahasiswa yang bertanya sebelum diakhirnya perkuliahan.

\section{Hasil Obsevasi Kedua}

Observasi ke 2 dilakukan pada hari Jumat, 2 November 2018 pada pukul 10.00-11.30. pada observasi ke 2 materi yang diajarkan yaitu 通知案内のメモ/iraiannaimemo (pengumuman pemberitahuan). Pada pertemuan ini dosen menyiapkan sumber belajar seperti media power point. Absensi dilakukan dengan bertanya kepada korti tentang ketidak hadiran mahasiswa.

Setelah melakukan absensi dosen memberikan fukushu materi sebelumnya. Pembelajaran dimulai dengan mengaitkan materi sebelumnya dengan yang akan dibahas. Pembelajaran berlangsung dengan keaktifan mahasiswa menjawab pertanyaan dari dosen tentang materi sebelumnya, sehingga suasana kelas berlangsung cukup santai dan gemuruh. Pembahasan materi tidak begitu sulit sehingga pemahaman mahasiswa cukup baik. Saat dosen mengarahkan tema yang dipelajari maka respon yang diberikan setiap mahasiswa sangat beragam. Seperti disaat dosen mengarahkan untuk membuat iraiannaimemo (pengumuman pemberitahuan), maka terdapat mahasiswa yang meresponnya dengan mengatakan "sulit" dan ada yang mengatakan "gampang", maka terkesan ada perdebatan mahasiswa. Tetapi setelah membahas tentang 通知案内のメモ/iraiannaimemo (pengumuman pemberitahuan) maka aka nada tugas dari dosen dengan membuat pengumuman terkait dengan bunkasai (ulang tahun jurusan). Tugas dibuat langsung dan boleh ditanyakan kepada dosen jika tidak yakin dengan kalimat atau kosa kata yang digunakan. Dengan begitu tugas bisa dikumpulkan pertemuan selanjutnya dan disempurnakan dirumah. Sebelum mengakhiri pembelajaran dosen memberikan kesempatan bertanya tentang materi yang diajarkan sekarang dan tugas yang akan dikumpul. 


\section{Hasil Obsevasi Ketiga}

Observasi ke 3 dilakukan pada hari Jumat, 9 November 2018 pada pukul 10.00-10.30. Pada observasi ke 3 ini berlangsung sedikit cepat karena dosen hanya menyuruh mengumpulakan tugas. Tugas yang dikumpul berupa selembar kertas yang berisi 通知案内のメ $モ /$ iraiannaimemo pengumuman pemberitahuan. Absensi tetap dilakukan. Setelah semua mengumpulkan tugas maka pertemuan diakhiri.

Berdasarkan observasi yang dilakukan terdapat pembelajaran yang dilakukan di luar kelas seperti, pembelajaran melalui online. Yang dimaksud pembelajaran online adalah pembelajaran yang dilakukan melalui media internet seperti pengiriman file materi dengan menggunakan email maupun sosial media lainnya. Sehingga dapat dikatakan pembelajaran diluar kelas termasuk proses pembelajaran. Dengan begitu dalam proses pembelajaran dapat dikatakan terlaksana dengan melalui media online, sehingga masuk dalam jurnal kegiatan belajaran mengajar.

Tidak hanya pemberian materi yang dilakukan dengan media online, pemberian tugas dilakukan dengan media online. Pengiriman tugas dengan memberikan petunjuk maupun syarat-syarat apa saja yang digunakan dalam pembuatan tugas. Setelah pembuatan tugas, tugas yang dikumpulkan yaitu berupa foto maupun hardcopy. Tugas tersebut dikumpulkan melalui email ataupun sosial media lain seperti Whats App. Dalam pengumpulan tugas yang sudah diberikan jadwal dan batas maka terhitung sebagai proses pembelajaran dan ditulis dalam jurnal kegiatan belajar mengajar.

\section{Hasil Obsevasi Keempat}

Observasi ke 4 dilakukan pada hari Rabu, 19 desember 2018 pada pukul 13.30-15.30 dengan dosem pengampu ke 2. Materi yang diajarkan pada pertemuan ini yaitu membahas tentang rirekisho (riwayat hidup). Sebelum memulai pembelajaran dosen melakukan absensi, dan media yang digunakan yaitu media berupa hard copy 3 lembar yang sudah disiapkan oleh dosen dan dibagikan kepada mahasiswa.

Pembahasan materi dengan menjawab soal yang sudah disiapkan tersebut, kemudian setelah dijawab akan dibahas secara bersama-sama dikelas. Dari 3 lembar terdapat 35 butir soal yang diambil dari tugas sebelumnya yaitu membuat rirekisho (riwayat hidup). Pembahasan soal dengan menunjuk satu persatu dari mahasiswa yang nantinya akan menjawab soal yang sudah ditentukan sehingga semua mahasiswa akan mendapat kesempatan untuk menjwab soal. Soal yang dibuat oleh dosen seperti kosakata yang kurang tepat digunakan pada rirekisho (riwayat hidup) dari masing-masing mahasiswa, dari 35 butir soal sudah dibahas dengan memperbaiki kosakata yang tepat sehingga setiap mahasiswa akan mengetahui kesalahan masing-masing. Pembahasan dilakukan dengan cara mengaitkan langsung dengan kehidupan sehingga pemahaman mahasiswa akan lebih cepat.

Setelah pembahasan soal selesai dosen melakukan evaluasi pembelajaran. Dosen memberikan pengarahan tentang tugas yang akan dikumpul pertemuan selanjutnya. Tugas yang dikumpulkan yaitu memperbaiki rirekisho (riwayat hidup) yang sudah dikumpul sebelumnya agar lebih sempurnakan. Dosen memberikan kesempatan kepada mahasiswa untuk bertanya jika ada yang tidak dipahami baik itu materi maupun tugas.

\section{Hasil Observasi Kelima}

Observasi ke 5 dilakukan pada hari Jumat, 21 Desember 2018 pada pukul 08.00-08.30 dengan dosen pengampu ke 2 . Tidak ada materi yang diajarkan pada pertemuan ini hanya mengumpulkan tugas yang sebelumnya sudah diberi tahu. Tugas yang dikumpul berupa rirekisho (riwayat hidup). Tugas yang dikumpulkan berupa 2 lembar hard copy yang sudah 
dilengkapi dengan rirekisho (riwayat hidup) dari masing-masing mahasiswa yang disertakan dengan foto. Absensi tetap dilakukan pada pertemuan ini. Setelah semua mengumpulkan tugas dosen mengakhiri pertemuan.

Pada observasi ke lima pertemuan sedikit cepat karena hanya mengumpulkan tugas yang sudah diberi tahukan minggu sebelumnya. Setelah mengumpulkan tugas dosen memberikan arahan-arahan mengenai bagaimana mata kuliah sakubun jokyu. Pertemuan didalam kelas tidak berlangsung lama, karena pada minggu sebelumnya sudah dijadwalkan bahwa pada pertemuan ini hanya mengumpulkan tugas.

Observasi dikelas dengan dosen pengampu ke 2 dilakukan sebanyak 2 kali. Karena pada sebelumnya dilakukan proses pembelajaran diluar kelas seperti belajar mandiri dan pembuatan tugas yang terhitung dalam proses pembelajaran.

\section{Strategi Pembelajaran Sakubun Jokyu}

Dalam suatu pembelajaran tentunya ada strategi atau materi yang digunakan sebagai alat untuk memberikan suatu materi. Pada pembelajaran Sakubun Jokyu di Program Studi Pendidikan Bahasa Jepang Universitas Pendidikan Ganesha dalam proses pembelajarannya tentu menggunakan beberapa strategi. Strategi yang digunakan seperti strategi ceramah, latihan, ekspositori, tanya jawab dan penugasan.

Pada strategi ceramah dosen memberikan materi dengan singkat sesuai dengan tema, pada tahap selanjutnya dosen lebih menggunakan strategi ekspositori seperti dosen menggali kemampuan setiap mahasiswa dan dosen memberikan materi dengan memberikan contohcontoh langsung yang berkaitan dengan materi.

Pada setiap materi maupun pertemuan dosen selalu melakukan tanya jawab diakhir amaupun awal pembelajaran sakubun. Tanya jawab merupakan strategi yang selalu digunakan oleh setiap pengajar dalam memberikan suatu materi.

Strategi latihan digunakan untuk melatih mahasiswa dalam pembuatan tugas maupun latihan yang hanya dilakukan untuk kegiatan rutin dalam suatu materi. Dalam pembelajaran sakubun latihan merupakan kegiatan yang rutin dilakukan oleh mahasiswa. Pada setiap akhir materi dosen selalu meminta mahasiswa untuk melakukan latihan didalam kelas.

Dalam strategi penugasan bertujuan untuk penialian dan tugas bertujuan mendapatkan hasil akhir dalam suatu materi. Pada pembelajaran sakubun dosen selalu memberikan tugas diakhir materi. Tugas yang diberikan dosen selain intuk penilaian adalah untuk melihat keaktifan dalam proses pembelaran. Pada setiap tugas yang dikumpulkan mahasiswa dosen akan memeriksa dan melihat ketepatan dalam mengumpulkan tugas. Selain itu batas waktu yang diberikan juga akan mempengaruhi nilai pada setiap mahasiswa. Jika terdapat mahasiswa yang terlambat mengumpulkan tugas maka akan mendapatkan sangsi maupun pengurangan nilai sesuai dengan kesepakatan bersama.

\section{Proses Capaian Pembelajaran Sakubun Jokyu}

1. Capaian Pembelajaran Sikap

Dalam suatu pembelajaran tentu ada beberapa capaian pembelajaran yang harus terpenuhi. Capaian pembelajaran pada setiap mata pelajaran atau mata kuliah tentu memiliki capaiancapaian yang berbeda. Seperti halnya capaian pembelajaran mata kuliah Sakubun Jokyu.

Pada capaian pembelajaran Sakubun Jokyu dinyatakan bahwa setiap mahasiswa memiliki tanggung jawab dalam menyelesaikan tugas dan mampu menulis artikel ilmiah dalam Bahasa Jepang dengan baik serta mempresentasikannya. Maka dalam pembelajaran setiap mahasiswa sudah melakukan tanggung jawabnya dengan baik, terlihat dari penyelesaian tugas dan ketepatan mengumpulkan tugas. Pengumpulan tugas pada setiap batas waktu / deadline yang diberikan telah dilakukan dengan baik oleh setiap mahasiswa. Ketepatan dalam mengumpulkan 
tugas termasuk dalam tanggung jawab yang harus dimiliki oleh setiap mahasiswa. Kemudian pada penulisan artikel Bahasa Jepang, setiap mahasiswa mampu menulis artikel dengan Bahasa Jepang. Dibuktikan dengan syarat yang diberikan oleh dosen yaitu dengan berbahasa Jepang dan seluruh mahasiswa selesai menuliskannya dalam Bahasa Jepang. Serta setiap mahasiswa mampu mempresentasikannya dengan pembahasan satu persatu tugas di depan kelas.

\section{Capaian Dalam Pembelajaran Pengetahuan}

Pada ranah pengetahuan ada beberapa aspek yang harus terpenuhi yaitu mengenal konsep teoritik tentang kosa kata, pola kalimat dan tuturan Bahasa Jepang tulis yang diterapkan dalam membuat artikel ilmiah serta penguasaan dalam mempresentasikannya. Dalam capaian pembelajaran pada ranah pengetahuan setiap mahasiswa harus memenuhi kriteria tersebut. Karena pada dasarnya pembelajaran Sakubun Jokyu berawal dari pengenalan kosakata, pola kalimat dan pembuatan artikel.

Dalam pembelajaran Sakubun Jokyu seluruh mahasiswa mampu memahami atau mengenal konsep tentang kosakata. Hal itu dibuktikan dengan pembahasan materi pada pembelajaran dan pemberian tugas yang berupa mencari kosakata baru yang berkaitan dengan materi di berbagai sumber. Selanjutnya kosakata tersebut dibahas untuk ketepatan dalam kaitannya dengan materi. Dengan mencari kosakata baru pada setiap materi akan membantu pemahaman setiap mahasiswa tentang konsep kosakata.

Pada pengenalan pola kalimat dosen terlebih dahulu memberikan contoh dan batasan dalam membuat pola kalimat. Dengan pemaparan pola kalimat yang terperinci maka setiap mahasiswa memiliki tugas untuk membuat pola kalimat baru yang berkaitan dengan materi. Secara langsung setiap mahasiswa harus membuat pola kalimat dan mengucapkan di dalam kelas. Dengan diberikannya tugas pada setiap mahasiswa maka akan terlihat tingkat pemahaman tentang konsep pola kalimat.

Dalam pembuatan artikel tentu hal yang dasar diketahui yaitu pemahaman kosakata dan pola kalimat. Karena dengan kosakata dan pola kalimat itu akan membentuk suatu karangan maupun artikel sesuai dengan tuntutan capaian pembelajaran. Dalam capaian pembelajaran ranah pengetahuan memiliki tiga tuntutan yaitu pemahaman kosakata, pola kalimat dan pemahaman konsep bahasa Jepang dalam pembutan artikel. Pada pemahaman pembuatan artikel dalam pembelajaran dosen memberikan kebebasan untuk mencari contoh artikel dari berbagai sumber. Hal itu bertujuan untuk mempermudah mahasiswa dalam mengenal konsep Bahasa jepang dalam artikel dan mengenal ragam tulis.

3. Capaian Pembelajaran Dalam Keterampilan Umum

Pada ranah keterampilan umum memiliki empat capaian pembelajaran yang harus diterapkan. Selain mengenal konsep kosakata dan pola kalimat pada capaian pembelajaran ranah pengetahuan, maka terdapat dua capaian pembelajaran tambahan pada ranah keterampilan umum yaitu mengenal dan memahami tuturan Bahasa Jepang dalam bentuk ragam tulis membuat artikel ilmiah dengan menunjukkan penguasaan kosakata dan pola kalimat dengan baik sesuai tema yang ditentukan, dan mampu menuliskan dalam bentuk huruf Jepang (hiragana, katakana dan kanji) serta mampu mempresentasikannya.

Capaian pembelajaran keterampilan umum menuntut mahasiswa untuk lebih meningkatkan kemampuannya dalam pemahaman kosakata maupun pola kalimat. Karena pada capaian ini mahasiswa dituntut untuk membuat artikel dengan bahasa Jepang serta dalam huruf Jepang.

Pada pembelajaran di kelas capaian pembelajaran diterapkan dengan dosen terlebih dahulu memastikan pemahaman kosakata dan pola kalimat mahasiswa cukup baik. Dengan cara melakukan tanya jawab tentang kosakata maupun pola kalimat yang berkaitan dengan materi. Selain itu dosen melakukan review untuk mengingatkan kembali materi sebelumnya dan menguji kemampuan mahasiswa dengan menunjuk satu persatu. Setelah memastikan 
kemampuan mahasiswa dalam pengusaan pola kalimat dan kosakata maka dilanjutkan dengan memberikan latihan membuat artikel dengan Bahasa Jepang sesuai dengan capaian pembelajaran yang harus tercapai pada pembuatan artikel dengan Bahasa Jepang. Pada tahap membuat artikel setiap mahasiswa diberikan kebebasan untuk menentukan materi dan mencari diberbagai sumber, seperti internet.

Latihan yang dilakukan di dalam kelas akan mempermudah mahasiswa dalam membuat artikel, karena dosen memberikan kebebasan untuk bertanya jika ada yang belum dipahami dan diperkenankan untuk melakukan diskusi dengan teman. Latihan yang diberikan secepat mungkin diselesaikan pada pembelajaran, hal itu disebabkan karena dosen agar bisa secara langsung mengoreksi jika ada kesalahan pada artikel. Setiap mahasiswa wajib memperlihatkan hasil pada dosen, setelah direvisi maka tujuan utamanya yaitu dosen meminta mahasiswa untuk membuat artikel dalam huruf Jepang baik itu hiragana, katakana dan kanji. Hal itu dilakukan untuk menerapkan capaian pembelajaran dalam pembuatan artikel dengan menggunakan huruf Jepang.

4. Capaian Pembelajaran Dalam Keterampilan Khusus

Pada keterampilan khusus terdapat beberapa capaian pembelajaran yaitu keterampilan dalam memahami kosakata, pola kalimat, pemahaman ragam tulis dalam membuat artikel dan mampu menuliskan artikel ilmiah dengan Bahasa Jepang serta Huruf Jepang.

Pada keterampilan memahami pola kalimat dan kosakata ditunjukkan dengan keaktifan mahasiswa pada pembuatan artikel dengan mencari contoh-contoh kosakata dan pola kalimat pada berbagai sumber seperti kamus, internet dan sumber ajar. Selain itu pada pembelajaran dikelas mahasiswa terlihat menggunakan Bahasa Jepang ketika bertanya dengan dosen.

Penulisan artikel dengan huruf Jepang terlihat ketika dosen memberikan tugas latihan di dalam kelas dan terlihat beberapa mahasiswa telah membuat dengan huruf Jepang baik itu (hiragana, katakana dan kanji). Dalam pengumpulan tugas terlihat pula tugas yang dikumpulkan dengan menggunakan Bahasa Jepang. Pada penulisan artikel dosen memberikan informasi bahwa dalam penulisan artikel secara umum menggunakan huruf Jepang (kanji). Jika terdapat huruf hiragana dan katakana itu hanya pada kosakata tertentu. Maka dosen meminta untuk berhati-hati dalam membuat artikel serta memperhatikan penulisannya.

\section{Simpulan Dan Saran}

Berdasarkan hasil penelitian dan pembahasan mengenai kurikulum KKNI pada mata kuliah Sakubun Jokyu di program Studi Pendidikan Bahasa Jepang Universitas Pendidikan Ganesha sebagai berikut.

1. Pada tahap perencanaan, seluruh dokumen sudah terpenuhi sesuai dengan kriteria yang berlaku di Universitas Pendidikan Ganesha yang berbasis KKNI. Perencanaan tersebut meliputi Silabus, RPS, Kontrak Kuliah dan Deskripsi Mata Kuliah.

2. Pada proses pembelajaran dosen menggunakan pendekatan pembelajaran dengan benar pada setiap tatap muka. Pada proses pembelajaran terdapat kendala yang membuat pertemuan tatap muka tidak berlangsung, maka dari itu dosen melakukan proses pembelajaran diluar kelas atau belajar mandiri dan berkelompok dengan mengirimkan materi melalui media online.

Pada proses penilaian dosen melakukan dengan lebih mengutamakan proses belajar dibandingkan dengan hasil. Pada penilaian proses yang dinilai adalah kehadiran dan keaktifan dalam belajaran seperti bertanya dan menjawab pertanyaan. Selain melihat proses belajar, dosen tetap menggunkan nilai tugas dan nilai UTS UAS sebagai nilai utama.

\section{Saran}


Berdasarkan hasil penelitian maka dapat disarankan hal-hal sebagai berikut.

1. Dalam perubahan kurikulum membuat konsekuensi pada proses pembelajaran dan pengajar. Maka dari itu dalam perubahan kurikulum ini dosen maupun mahasiswa harus lebih siap dalam menghadapi perubahan.

2. Pelaksanaan pembelajaran dengan bertatap muka seharusnya lebih rutin dilakukan sesuai dengan RPS. Karena selain untuk mengukur dan melihat perkembangan mahasiswa yang terpenting adalah untuk mengevaluasi proses pembelajaran.

3. Dalam pelaksanaan pembelajaran sebaiknya dosen tidak menggunakan metode ceramah dalam pemberian materi, karena metode ceramah tidak sesuai dengan tuntutan kurikulum KKNI.

\section{DAFTAR PUSTAKA}

Dewi, Faradita Septian Nanda. (2015). Penerapan Model Pembelajaran Induktif Kata Bergambar Untuk Meningkatkan Kemampuan Menulis Karangan Bahasa Jepang Pada Siswa Kelas XI IPA 4 SMAN 1 Selemadeg Semester Genap Tahun Ajaran 2014/2015. Universitas Pendidikan Ganesha.

Dahidi, Ahmad. Ihwal Pembelajaran Menulis (Sakubun) Di Program Pendidikan Bahasa Jepang FBS UPI.

Magoma, M.Charles.(2016). "The Shift and Emphasis Towards Curriculum Integration : Meaning and Rationale". Vol. 4(2),pp. 25-30.

Meidani, Wawan. (2006). Peranan Mata Kuliah Mengarang (Sakubun) Dalam Pembelajaran Bahasa Jepang. Universitas Indonesia.

Pratama, W. Nanda Putri Harni. (2019). Analisis Implementasi Kurikulum 2016 Berbasis KKNI pada Mata Kuliah Kanji Jokyu di Program Studi Pendidikan Bahasa Jepang Universitas Pendidikan Ganesha. Singaraja.

Riyani, Riri. (2012). Pengaruh Penulisan Catatan Harian Mahasiswa Pada Ansyokyu Sakubun I Di UPI.

Sanusi, dkk. 2016. "Pengembangan Bahan Ajar Berorientasi KKNI Untuk Penguatan Scientific pproach Pada Mata Kuliah Evaluasi Dan Proses Pembelajaran Matematika". Vol 8, No 1, hlm 1189-1249

Setiawan, Deni. (2017). "Pengembangan Model Kurikulum Berorientasi KKNI Di FIS Universitas Negeri Medan".Vol. 1, No. 1 Hal. 581-586.

Salirawati, Das. (2014). "Kurikulum 2013, KKNI dan Implementasinya". Vol. 5, No. 1.

Sanusi, Murtafiah dan Suprapto. (2016). "Pengembangan Bahan Ajar Berorientasi KKNI Untuk Penguatan Scientific Approach Pada Mata Kuliah Evaluasi dan Proses Pembelajaran Matematika di IKIP PGRI Madiun". Vol. 8, No 1, hlm 1189-1249. 